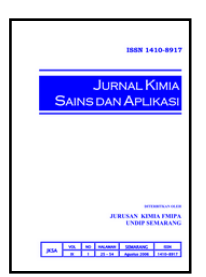

\title{
Isolasi Bakteri Termofilik Sumber Air Panas Gedongsongo dengan Media Pengaya MB (Minimal Broth) dan TS (Taoge Sukrosa) serta Identifikasi Fenotip dan Genotip
}

\author{
Dewi Nuritasari ${ }^{a}$, Purbowatiningrum Ria Sarjono ${ }^{a^{*}}$, Agustina L.N. Aminin ${ }^{\text {a }}$ \\ a Biochemistry Laboratory, Chemistry Department, Faculty of Sciences and Mathematics, Diponegoro University, Jalan Prof. \\ Soedarto, Tembalang, Semarang 50275 \\ * Corresponding author: purbowatining@live.undip.ac.id
}

\begin{tabular}{l}
\hline Article Info \\
\hline Keywords: \\
thermophilic \\
bacteria, Gedong \\
songo hot springs, \\
16S rRNA, \\
extracellular \\
enzymes
\end{tabular}

\section{Abstract}

Thermophilic bacteria is a bacteria that can survive at high temperatures where one of the habitat is the source of hot water. Indonesia has many potential hot water as a habitat for thermophilic bacteria. In this research, thermophilic bacteria was isolated from Gedongsongo hot springs using minimal approach MB media (Minimal Broth) and TS (Taoge Sukosa) and of phenotypes identification with microbiology test including gram staining and morphology and genotypic identification using gene nucleotide sequence of $16 \mathrm{~S}$ rRNA and phylogenetic tree construction using Phylip 3.68 ed program Distance matrix method (Neighbor joining). A qualitative extracellular enzyme identification was performed using selective media including cellulase test, $\alpha$-amylase test, protease test and $\mathrm{P}$-galactosidase test. From the research, it was obtained two isolates of thermophilic bacteria, namely GS_MBan isolate and GS_TSan isolate. The GS_MBan isolate had a resemblance to the bacterial group of Anoxybacillus sp. up to 94$99 \%$, rod in shaped, gram-positive bacteria, have extracellular enzyme a-amylase, protease and P-galactosidase and do not show the potential of extracellular cellulase enzyme. The GS_TSan isolate resembled the bacterial group Thermoanaerobacterium sp. of 78-86\%, rod-shaped, gram-negative bacteria, have extracellular $\alpha$-amylase and protease enzymes and did not show potential extracellular enzyme P-galactosidase and cellulase. The GS_TSan isolate resembled the bacterial group Thermoanaerobacterium sp. of $78-86 \%$, rod-shaped, gram-negative bacteria, had an extracellular $\alpha$-amylase and protease enzymes and do not show potential extracellular enzyme P-galactosidase and cellulase.

\section{Abstrak}

Kata kunci: bakteri termofilik, sumber air panas Gedongsongo, $16 \mathrm{~S}$ rRNA,enzim ekstraseluler
Bakteri termofilik merupakan bakteri yang mampu bertahan hidup pada suhu tinggi di mana salah satu habitatnya adalah sumber air panas. Indonesia memiliki banyak sumber air panas yang potensial sebagai habitat bakteri termofilik. Dalam penelitian ini dilakukan isolasi bakteri termofilik sumber air panas gedongsongo dengan menggunakan pendekatan minimal media MB (Minimal Broth) dan TS (Taoge Sukosa) serta identifikasi fenotip dengan uji mikrobiologi yang meliputi pewarnaan gram dan morfologi dan identifikasi genotip dengan menggunakan urutan nukleotida gen $16 \mathrm{~S}$ rRNA dan konstruksi pohon filogenetik dengan menggunakan program Phylip 3.68 ed. metode Distance matrix (Neighbour joining). Identifikasi enzim ekstraseluler secara kualitatif dilakukan dengan menggunakan media selektif yang meliputi uji selulase, uji a-amilase, uji protease dan uji P-galaktosidase. Dari penelitian diperoleh dua isolat tunggal bakteri termofilik yaitu isolat GS_MBan dan isolat GS_TSan. Isolat GS_MBan 
memiliki kemiripan dengan bakteri kelompok Anoxybacillus sp. sebesar 94-99\%, berbentuk batang, bakteri gram positif, memiliki enzim ekstraseluler a-amilase, protease dan $\mathrm{P}$-galaktosidase serta tidak menunjukkan potensi adanya enzim ekstraseluler selulase. Isolat GS_TSan memiliki kemiripan dengan bakteri kelompok Thermoanaerobacterium sp. sebesar $78-86 \%$, berbentuk batang, bakteri gram negatif, memiliki enzim ekstraseluler a-amilase dan protease serta tidak menunjukkan potensi adanya enzim ekstraseluler P-galaktosidase dan selulase.

\section{Pendahuluan}

Bakteri ekstermofil merupakan mikroorganisme yang tumbuh dengan subur pada lingkungan ekstrem. Salah satu jenis bakteri ekstremofil adalah bakteri termofilik yang dapat didefinisikan sebagai organisme yang dapat hidup pada suhu tinggi [1]. Bakteri termofilik memiliki habitat yang bermacam-macam seperti di letupan hidrothermal [2, 3], sumber air panas [4, 5], tumpukan kompos [6], atau pemanas air [7]. Bakteri jenis termofilik tersebut sering diteliti untuk mengetahui protein termostabilnya.

Identifikasi jenis-jenis bakteri secara mikrobiologi konvensional dapat dilakukan dengan menggunakan media selektif yang mampu membedakan antara jenis bakteri satu dengan yang lain. Selain itu, identifikasi jenis-jenis bakteri juga dapat dilakukan dengan metode fenotip, yaitu melalui uji morfologi dan biokimia [8]. Akan tetapi cara identifikasi ini memiliki beberapa kekurangan dengan adanya keterbatasan media pengkulturan [9]. Oleh karena itu ilmuwan mengembangkan identifikasi secara genotip untuk mengganti metode konvensional tersebut. Uji genotip memiliki banyak keuntungan diantaranya lebih mudah, lebih valid dan lebih cepat. Uji genotip dilakukan berdasarkan urutan nukleotida gen 16S rRNA karena memiliki sifat lestari dan diturunkan dari generasi ke generasi dengan urutan yang tetap [10], 1994). Selain itu, identifikasi urutan nukleotida gen 16S rRNA ternyata dapat digunakan untuk menentukan hubungan kekerabatan bakteri berdasarkan konstruksi pohon filogenetiknya dan untuk mengidentifikasi bakteri yang belum diketahui jenisnya.

Berdasarkan penelitian Aminin dkk. [11] diperoleh beberapa bakteri unik khas Gedongsongo dari kelompok Thermus dan Beta-proteobacteria yang ditumbuhkan pada minimal media MB (Minimal Broth) dan TS (Taoge Sukrosa) dalam kondisi anaerob yang terdeteksi sebagai kultur campuran. Berdasarkan penelitian tersebut, maka pada penelitian ini dilakukan isolasi bakteri sumber air panas Gedongsongo dengan pendekatan minimal media MB dan TS untuk mendapatkan isolat tunggal dan dilakukan karakterisasi berdasarkan uji fenotip dan genotip. Uji fenotip meliputi uji morfologi dan identifikasi kualitatif enzim ekstraseluler yaitu uji selulase, uji P-galaktosidase, uji a-amilase dan uji protease. Uji genotip dilakukan berdasarkan identifikasi urutan nukleotida gen 16S rRNA dan pembuatan pohon filogenetik.

\section{Metodologi}

\section{Sampling}

Sampel air diambil dari sumber air panas Gedongsongo, daerah gunung Ungaran, Jawa Tengah, Indonesia ( $110^{\circ} 22^{\prime} 23.4^{\prime \prime} \mathrm{E}$; $07^{\circ} 12$ '08.5"S; dan ketinggian $1400 \mathrm{~m} \mathrm{dpl}$ ) dan dimasukkan ke dalam tabung bertutup berisi media. Dua media sederhana telah dipilih sebagai sumber karbon dan mengandung vitamin dan mineral yang dibutuhkan untuk pertumbuhan bakteri, yaitu TS $(0,02 \%(\mathrm{v} / \mathrm{v})$ filtrat taoge dan $0,04 \%(\mathrm{w} / \mathrm{v})$ sukrosa dan $M B(0,02 \%(\mathrm{w} / \mathrm{v})$ beef extract, $0,02 \%(\mathrm{w} / \mathrm{v})$ pepton, dan $0,01 \%(\mathrm{w} / \mathrm{v}) \mathrm{NaCl})[12]$.

\section{Pembiakan dalam media MB dan TS}

Hasil sampling kemudian diinkubasi pada suhu $55^{\circ} \mathrm{C}$. Inkubasi dilakukan pada kondisi anaerob dengan meletakan tabung-tabung yang berisi biakan ke dalam toples dengan nyala lilin untuk mengurangi ketersediaan oksigen. Inkubasi dihentikan dan sel dipanen setelah adanya kekeruhan pada media. Bakteri yang telah tumbuh kemudian ditumbuhkan kembali pada media padat dengan menggunakan metode tuang untuk mendapatkan koloni tunggalnya.

\section{Uji pewarnaan gram}

Pewarnaan gram dilakukan dengan menambahkan pewarna gram secara bertahap. Kaca preparat yang digunakan dibersihkan dengan alkohol kemudian dipanaskan di dekat nyala api. Isolat bakteri kemudian diambil dengan menggunakan jarum ose dan diratakan pada kaca preparat, lalu dipanaskan di dekat api sambil digoyang-goyangkan hingga isolat kering. Saat pemanasan diusahakan agar api tidak terkena langsung. Isolat bakteri ditetesi dengan kristal ungu, didiamkan selama 1 menit, dicuci dengan akuades dan dikeringkan dengan cara dianginkan. Hasil pewarnaan kristal ungu ditetesi iodin, didiamkan selama 1 menit, diicuci dengan akuades dan dikeringkan. Hasil pewarnaan iodin ditetesi dengan alkohol absolut, didiamkan selama 30 detik, dicuci dengan akuades dan dikeringkan. Langkah terakhir, hasil yang diperoleh dari pewarnaan dengan alkohol absolut ditetesi dengan safranin kemudian dicuci dengan akuades. Hasil pewarnaan safranin kemudian dikeringkan dan hasilnya diamati dengan mikroskop [13].

\section{Isolasi DNA kromosom}

\section{Metode Zhou modifikasi}

Kultur bakteri dimasukkan ke dalam mikrotub 1,5 $\mathrm{mL}$, kemudian disentrifugasi dengan kecepatan 5000 rpm selama 5 menit untuk memperoleh pelet sel. Pelet 
sel dicampur dengan $300 \mathrm{pL}$ buffer ekstraksi DNA (100mM Tris-HCl [pH 8,0], 100mM Na-EDTA [pH 8,0], $100 \mathrm{mM}$ sodium fosfat [pH 8,0] dan 1,5 M NaCl). Larutan ditambah dengan $10 \mathrm{pL}$ proteinase $\mathrm{K}$ $(20 \mathrm{mg} / \mathrm{mL})$ dan $0,2 \mathrm{~g}$ pasir laut steril dalam $1,5 \mathrm{~mL}$ mikrotub dengan penggojogan selama 10 menit. Setelah digojog, ditambahkan 30 pL 20\% SDS (Sodium Dodesil Sulfonat) dan sampel diinkubasi pada suhu $60^{\circ} \mathrm{C}$ selama 1 jam dan digojog setiap 15-20 menit. Supernatan dikumpulkan menjadi satu setelah disentrifugasi pada 5.000 rpm selama 10 menit pada suhu ruang dan dipindahkan ke dalam mikrotub. Supernatan ditambah dengan kloroform-isoamil alkohol (24:1, v/v) pada volume yang sama. Fase cair didapatkan kembali dengan sentrifugasi dan pengendapan dengan 1 volume isopropanol pada suhu ruang selama 15 menit. Pelet kasar asam nukleat didapat dengan sentrifugasi pada 12.000 rpm selama 10 menit pada suhu ruang, lalu dicuci dengan etanol $70 \%$ dingin, dan dilarutkan kembali dalam dd $\mathrm{H}_{2} \mathrm{O}$ steril sampai memberi volume akhir $50 \mathrm{pL}$ [12].

\section{Metode freeze thawing modifikasi}

Kultur bakteri dimasukkan ke dalam mikrotub 1.5 $\mathrm{mL}$, kemudian disentrifugasi dengan kecepatan 5000 rpm selama 5 menit untuk memperoleh pelet sel. Pelet sel disuspensikan ke dalam $100 \mathrm{pL} \mathrm{ddH}_{2} \mathrm{O}$ steril kemudian disentrifugasi dengan kecepatan $5000 \mathrm{rpm}$ selama 10 menit sebanyak tiga kali. Pelet sel yang diperoleh kemudian disuspensikan kembali ke dalam $100 \mathrm{pL} \mathrm{ddH}_{2} \mathrm{O}$ steril. Suspensi sel kemudian dipanaskan di dalam air mendidih selama 20 menit dan dilanjutkan dengan pendinginan dengan temperatur $-20^{\circ} \mathrm{C}$ selama 10 menit. Setelah pendinginan, suspensi sel disentrifugasi dengan kecepatan 12000 rpm selama 10 menit pada suhu ruang.

\section{Amplifikasi gen 16S rRNA}

Sampel DNA kromosom yang diperoleh selanjutnya diamplifikasi secara in vitro dengan metode PCR. Bagian gen 16S rRNA diamplifikasi menggunakan satu set primer universal $27 \mathrm{~F}-1492 \mathrm{R}$, pasangan primer $27 \mathrm{~F}$ : 5'AGA GTT TGA TCC TGG CTC AG 3' (posisi 8-27, penomoran urutan basa E.coli) dan 1492R: 5'GGT TAC CTT GTT ACG ACT T 3' (posisi 1492-1510, penomoran urutan basa E.coli) [14]. Sebanyak 5 pL templat DNA hasil lisis dimasukkan ke dalam mikrotub, kemudian ditambah $43 \mathrm{pL}$ Mega Mix Blue PCR kit, $1 \mathrm{pL}$ primer 27F dan 1 pL 1492R. Tiap sampel kemudian dimasukkan ke alat PCR dan dikerjakan sebanyak 30 siklus [15]. Tahap denaturasi dilakukan pada suhu $94^{\circ} \mathrm{C}$ selama 1 menit, tahap annealing dilakukan pada suhu $54^{\circ} \mathrm{C}$ selama 45 menit, dan tahap extension dilakukan pada suhu $72^{\circ} \mathrm{C}$ selama 2 menit tahap. Pada siklus ke 30, tahap extension dilakukan selama 10 menit dan dilanjutkan dengan penurunan suhu sampai $4^{\circ} \mathrm{C}$.

\section{Elektroforesis fragmen gen 16S rRNA}

Sebanyak 0,2 gram agarosa dilarutkan ke dalam 20 mL TBE (Tris Borat EDTA) 1X kemudian dipanaskan hingga mendidih. Hasil pemanasan kemudian ditambahkan dengan $4 \mathrm{pL}$ etidium bromida dan diaduk agar tercampur sempurna lalu dituang ke dalam cetakan yang telah dipasangi sisir untuk membuat sumursumur (well) dan didiamkan hingga padat. Setelah gel memadat, sisir kemudian dilepas. Proses selanjutnya sebanyak 3 pL hasil PCR dimasukkan ke dalam sumur (well) gel kemudian dimasukkan ke dalam alat elektroforesis hingga terendam oleh larutan TBE $1 \mathrm{X}$ dan dilakukan pengelektroforesisan terhadap sampel dengan arus $400 \mathrm{~mA}$ dan tegangan $100 \mathrm{~V}$. Elektroforesis dihentikan apabila pergerakan sampel telah sampai pada ujung gel. Gel kemudian diamati di bawah sinar ultraviolet menggunakan lampu UV Transiluminator untuk mengetahui pola pita-pita DNA [15].

\section{Analisis sekuensing}

Hasil PCR yang sudah terbukti mengandung fragmen gen 16S rRNA disekuensing di Korea oleh Macrogen Sequencing Service. Hasil yang diperoleh berupa urutan DNA forward dan reverse kemudian diedit dengan menggunakan program DNASTAR (EditSeq dan SeqMan) untuk menggabungkan dua sekuen DNA. Program EditSeq dipilih lalu data sekuen DNA dimasukkan dan dihasilkan output. Hasil (output) dari program EditSeq kemudian digunakan sebagai input pada program SeqMan. Hasil (output) dari program Seqman berupa urutan DNA utuh selanjutnya dibandingkan dengan data GenBank dan dilakukan studi filogeni.

\section{Studi filogeni}

Hasil sekuensing isolat GS_MBan dan isolat GS_TSan dibandingkan dengan data GenBank menggunakan program BLASTN (Basic Local Allignment Search Tool Nucleotide) yang terdapat pada NCBI (National Centre of Biotechnological Information) (www.ncbi.nlm.nih.gov). Hasil berupa data urutan nukleotida DNA kromosom bakteri-bakteri terdekat kemudian dilakukan studi filogeni dengan penjajaran menggunakan program Clustal W, konstruksi pohon filogenetik dengan program PHYLIP 3.68 (seqboot, DNAdist, neighbor dan consense) dan Phylodendron (online). Hasil BLASTN diedit dengan menghapus bagian subject hingga menyisakan bagian query pada data penjajaran nukleotida untuk masing-masing spesies bakteri dan meng-copy dalam bentuk notepad. Selanjutnya dilakukan penjajaran urutan nukleotida gen 16S rRNA dari isolat GS_MBan dan isolat GS_TSan dan bakteri lainnya dalam program Clustal W sehingga dihasilkan 4 data output dengan format '.aln', '.msf, '.dnd', dan '.phy'. Output dalam format '.phy' digunakan dalam tahap selanjutnya.

Konstruksi pohon filogenetik terhadap isolat GS_MBan dan isolat GS_TSan dilakukan dengan menggunakan program Phylip (Phytogeny Inference Package) 3.68 ed. dan dipilih program seqboot, DNAdist, neighbor dan consense. Hasil penjajaran dengan program Clustal W dalam format '.phy' digunakan sebagai data input pada program seqboot dan diperoleh output yang kemudian digunakan sebagai input pada program DNAdist. Output dari program DNAdist kemudian digunakan sebagai input pada program neighbor dan output dari neighbor dijadikan sebagai input pada program consense. Selanjutnya, output dari 
consense dalam bentuk data newick dimasukkan pada program Phylodendron dengan mengakses (http://iubio.bio.indiana.edu/treeapp/treeprint-

form.html) secara online sehingga diperoleh gambar pohon filogenetiknya.

\section{Identifikasi enzim fi-galaktosidase}

Sebanyak $25 \mathrm{pL}$ nutrien dan $25 \mathrm{~mL}$ air sumber yang telah diberi $0,25 \mathrm{~g}$ laktosa sebagai induser dimasukkan ke dalam tabung lalu diautoklaf. Sebanyak $10 \mathrm{pL}$ kultur bakteri diinokulasikan ke dalam media yang telah diautoklaf lalu diinkubasi sampai timbul kekeruhan. Sebanyak 0,1 mL ONPG ditambahkan pada kultur tersebut kemudian sampel diinkubasi selama 5 jam. Aktivitas enzim p- galaktosidase ditunjukkan dengan timbulnya warna kuning pada kultur [16].

\section{Identifikasi enzim $\alpha$-amilase}

Sebanyak $30 \mathrm{~mL}$ air sumber ditambah dengan $30 \mathrm{pL}$ nutrien, 0,45 $\mathrm{g}$ bacto agar dan $0,3 \mathrm{~g}$ pati diautoklaf kemudian dituang ke dalam cawan petri. Setelah media memadat, sebanyak 0,5 pL kultur bakteri diinokulasikan ke media kemudian diinkubasi sampai koloni bakteri tumbuh. Dilakukan penggenangan terhadap hasil inkubasi dengan larutan iod untuk mengetahui aktivitas enzim a-amilase yang ditunjukkan dengan terbentuknya zona bening di sekitar bakteri [17].

\section{Identifikasi enzim protease}

Sebanyak $10 \mathrm{~mL}$ air sumber dimasukkan ke dalam tabung reaksi kemudian ditambah dengan 10 pL nutrien dan diautoklaf. Sebanyak 0,3 g gelatin ditambahkan ke dalam media dan 20 pL kultur bakteri diinokulasikan lalu diinkubasi sampai timbul kekeruhan pada larutan. Tabung tersebut kemudian dimasukkan ke dalam lemari es selama 24 jam. Aktivitas enzim protease ditunjukkan dengan tetap mencairnya larutan setelah didinginkan [18].

\section{Identisikasi enzim selulase}

Sebanyak $30 \mathrm{~mL}$ air sumber ditambah dengan $30 \mathrm{pL}$ nutrien, 0,45 g bacto agar dan 0,15 g CMC diautoklaf kemudian dituang ke dalam cawan petri. Setelah media memadat, sebanyak 0,5 pL kultur bakteri diinokulasikan ke media kemudian diinkubasi sampai bakteri tumbuh. Dilakukan penggenangan terhadap hasil inkubasi dengan larutan congo red $1 \%$ selama 20 menit lalu dilakukan pencucian dengan larutan $\mathrm{NaCl} 1 \mathrm{M}$. Aktivitas enzim selulase ditunjukkan dengan terbentuknya zona bening di sekitar bakteri [19].

\section{Hasil dan Pembahasan}

\section{Pembiakan Kultur Bakteri}

Sampel air diambil dari sumber air panas Gedongsongo yang mempunyai $\mathrm{pH} 6$ dan suhu $68^{\circ} \mathrm{C}$ kemudian dikulturkan pada media MB (Minimal Broth) dan TS (Taoge-Sukrosa) dengan kondisi minimal sebagai media pertumbuhan bakteri mengacu pada penelitian sebelumnya [11]. Media MB terdiri dari pepton sebagai sumber nitrogen organik, beef extract sebagai sumber karbon dan pelengkap fungsi nutrisi dari pepton dengan menyumbang mineral-mineral dan $\mathrm{NaCl}$ yang berfungsi sebagai sumber mineral.

Media TS terdiri dari ekstrak taoge dan sukrosa sebagai sumber makronutrien dan mikronutrien yang dibutuhkan bagi pertumbuhan bakteri [20]. Penumbuhan bakteri dilakukan pada suhu $55^{\circ} \mathrm{C}$ mengacu pada penelitian sebelumnya dengan teknik candle jar (nyala lilin dalam toples) untuk mengurangi ketersediaan oksigen di lingkungan. Bakteri yang telah tumbuh di media cair kemudian ditumbuhkan kembali dalam media padat untuk mendapatkan single colony nya seperti pada gambar 1.

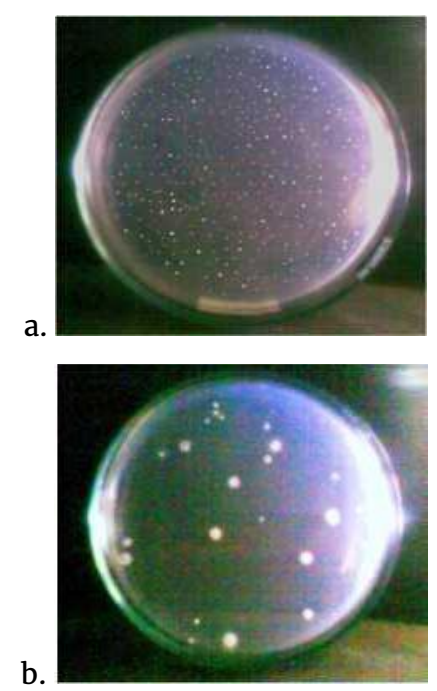

Gambar 1. Pertumbuhan bakteri pada media padat (a) Pertumbuhan bakteri pada media MB (b) Pertumbuhan bakteri pada media TS

Dari hasil pewarnaan gram (gambar 2) diketahui bahwa bakteri isolat GS_MBan merupakan bakteri gram positif berbentuk batang dan bakteri isolat GS_TSan merupakan bakteri gram negatif berbentuk batang.

a.

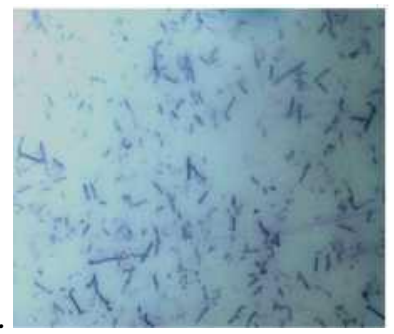

b.

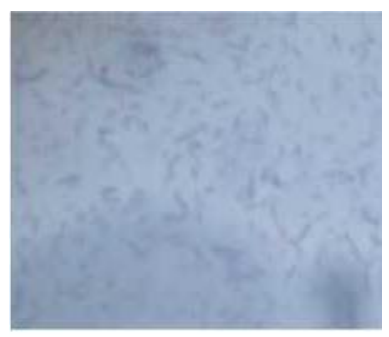

Gambar 2. Hasil pewarnaan gram terhadap bakteri isolat GS_MBan dan isolate GS_TSan (a) Bakteri isolat GS_MBan (b) Bakteri isolat GS_TSan 


\section{Amplifikasi Gen 16S rRNA Secara In Vitro}

Identifikasi secara genotipik terhadap bakteri yang telah diisolasi memerlukan templat DNA kromosom untuk proses PCR. Langkah awal untuk identifikasi genotipik adalah isolasi DNA kromosom yang dilakukan dengan menggunakan dua metode yaitu metode Zhou dan freeze thawing (beku leleh). Perusakan dinding sel pada metode Zhou dilakukan secara fisik menggunakan pasir laut steril dan secara kimiawi menggunakan SDS, sedangkan metode freeze thawing menggunakan prinsip perubahan temperatur ekstrim untuk perusakan dinding sel.

DNA kromosom hasil isolasi baik dengan metode Zhou maupun freeze-thawing kemudian digunakan sebagai templat amplifikasi fragmen gen 16S rRNA dengan metode PCR. Amplifikasi gen 16S rRNA dilakukan dengan dua primer uji (27F dan 1492R) yang akan membatasi amplifikasi bagian depan (forward) pada urutan 8 - 27 dan bagian belakang (reverse) pada urutan 1492 - 1510 berdasarkan penomoran urutan basa E. coli. Hasil PCR dianalisis dengan menggunakan elektroforesis gel agarosa dan divisualisasi dengan bantuan lampu UV [15] seperti pada gambar 3.

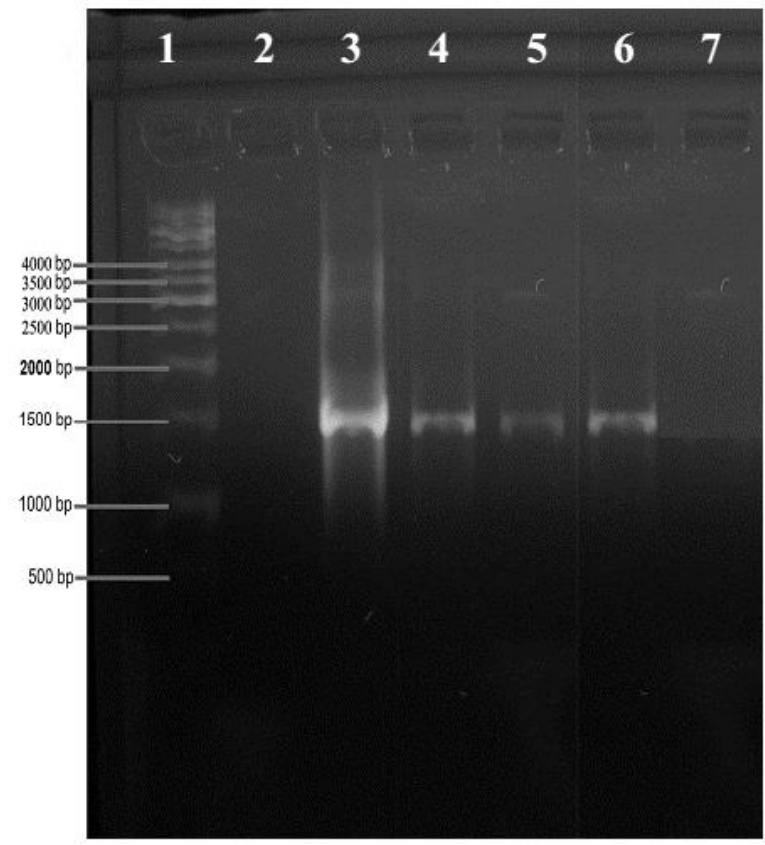

Gambar 3. Elektrofogram fragmen gen 16S rRNA hasil PCR
Keterangan : Sumur $1=$ Marker; Sumur $2=$ kontrol negatif; Sumur 3 = pita DNA E. coli; Sumur $4=$ pita DNA isolat GS_MBan metode freeze-thawing; Sumur $5=$ pita DNA isolat GS_TSan metode freeze-thawing; Sumur 6 = pita DNA isolat GS_MBan metode Zhou; Sumur 7 = pita isolat GS_TSan metode Zhou Dari elektroforegram yang tampak pada gambar 3, menunjukkan bahwa amplifikasi gen 16S rRNA baik dengan metode Zhou maupun metode freeze-thawing telah berhasil dilakukan dengan baik. Hal ini terbukti dengan adanya pita-pita tunggal pada daerah sumur gel masing-masing amplikon yang sejajar dengan marker 1500pb yang merupakan ukuran fragmen gen 16S rRNA. Namun pada sumur gel yang berisi hasil amplifikasi (amplikon) DNA isolat GS_TSan (sumur 7) tidak terdapat jejak pita.

\section{Analisis Hasil Sekuensing}

Hasil sekuensing berupa data elektroforegram seperti tampak pada gambar 4. Diperoleh urutan basa nukleotida isolat GS_MBan dan isolat GS_TSan yang kemudian urutan nukleotida tersebut digunakan sebagai dasar konstruksi pohon filogenetik untuk mengetahui hubungan kekerabatannya.

\section{Studi Filogeni}

Urutan nukleotida yang diperoleh dari sekuensing kemudian dibandingkan dengan data pada Genebank menggunakan program BLASTN pada website National Center of Biotechnology Information (NCBI). Hasil pembandingan urutan nukleotida gen 16S rRNA isolat GS_MBan dan isolat GS_TSan dengan data dari BLASTN pada gambar 5 menunjukkan bahwa isolat GS_MBan mempunyai kemiripan dengan 99 bakteri termofilik yang lain dengan tingkat homologi sebesar $9499 \%$ sedangkan isolat GS_TSan menunjukkan kemiripan dengan 95 bakteri termofilik yang lain dengan tingkat homologi sebesar 78-86\% di mana dari kelompok ini masih banyak bakteri yang belum terkulturkan (uncultured).

Konstruksi pohon filogenetik dilakukan dengan menggunakan program Phylip 3.68 ed, metode distance matriks. Data Newick yang merupakan hasil dari running program Phylip 6.38 dimasukkan dalam program Phylodendron-Phylogenetic tree printer (http:Ziubio.bio.indiana.edu) untuk mendapatkan pohon filogenetiknya. Hasil konstruksi pohon filogenetik seperti tampak pada gambar 5 dan gambar 6.

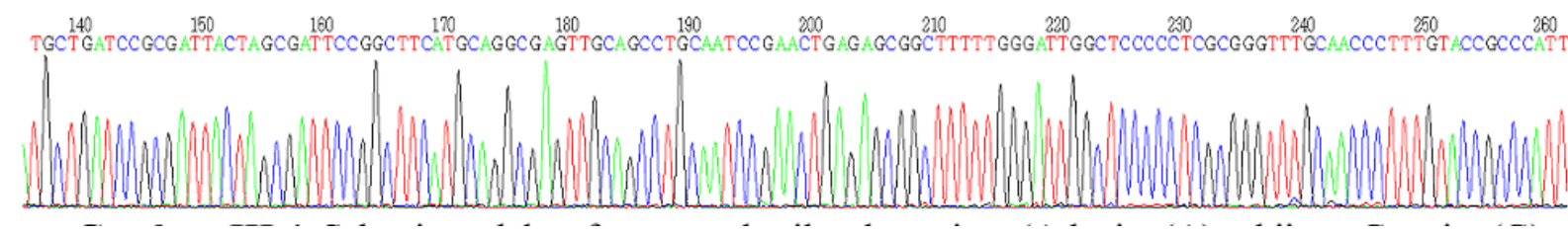

Gambar 4. Sebagian elektroforegram hasil sekuensing (Adenin $(A)=$ hijau; Guanin $(G)=$ hitam; Sitosin $(C)=b i r u$; dan $\operatorname{Timin}(\mathrm{T})=$ merah $)$ 
Tabel 1. Perbandingan bakteri hasil isolasi

\begin{tabular}{|c|c|c|c|c|c|}
\hline & \multirow{2}{*}{ Bakteri terdekat } & \multirow{2}{*}{$\begin{array}{l}\text { Kemiripan } \\
\text { urutan } \\
\text { nukleotida }\end{array}$} & \multicolumn{2}{|r|}{ Karakter } & \multirow{2}{*}{ Ref. } \\
\hline & & & Isolat bakteri & Bakteri terdekat & \\
\hline $\begin{array}{l}\text { Isolat } \\
\text { GS_MBan }\end{array}$ & $\begin{array}{l}\text { Anoxybacillus contaminant } \\
\text { strain } 16222\end{array}$ & $98 \%$ & \multicolumn{2}{|c|}{$\begin{array}{l}\text { Anaerob, batang, suhu tumbuh Anaerob fakultatif; batang; suhu max. } \\
\begin{array}{ll}550 \mathrm{C}, \text { potensi a- amilase, } & 60^{\circ} \mathrm{C} \text {; suhu opt. } 40-50^{\circ} \mathrm{C} ; \mathrm{pH} \text { opt. } 7 ; \\
\text { protease, P-galaktosidase } & \text { potensi a-amilase, protease, katalase, } \\
& \text { pereduksi nitrat }\end{array}\end{array}$} & [21] \\
\hline $\begin{array}{l}\text { Isolat } \\
\text { GS_TSan }\end{array}$ & $\begin{array}{l}\text { Thermoanaerobacterium sp. } \\
\text { kpuo4 }\end{array}$ & $86 \%$ & \multicolumn{2}{|c|}{$\begin{array}{l}\text { Anaerob, batang, suhu tumbuh Bakteri termofilik, anaerob, digunakan } \\
\text { 550C, potensi a- amilase, dalam produksi etanol } \\
\text { protease }\end{array}$} & [22] \\
\hline
\end{tabular}

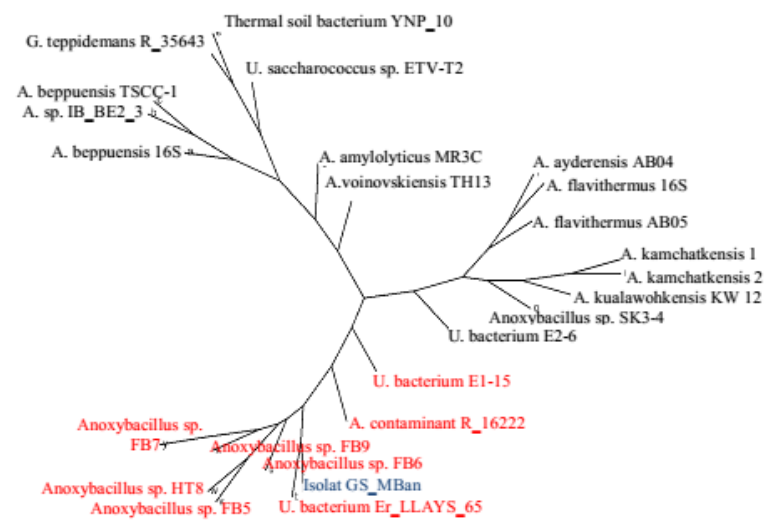

Gambar 5. Hasil konstruksi pohon filogenetik isolat GS_MBan dengan program Phylip 3.68 ed. metode Distance Matriks menggunakan model Tree diag (Keterangan: $\mathrm{A}=$ Anoxybacillus; $\mathrm{G}=$ Geobacillus; $\mathrm{U}=$ Uncultured)

Ket: Warna biru= isolat GS_MBan; Warna merah= spesies lain yang mempunyai hubungan kekerabatan terdekat dengan isolat GS_MBan; Warna hitam= spesies lain yang dibandingkan

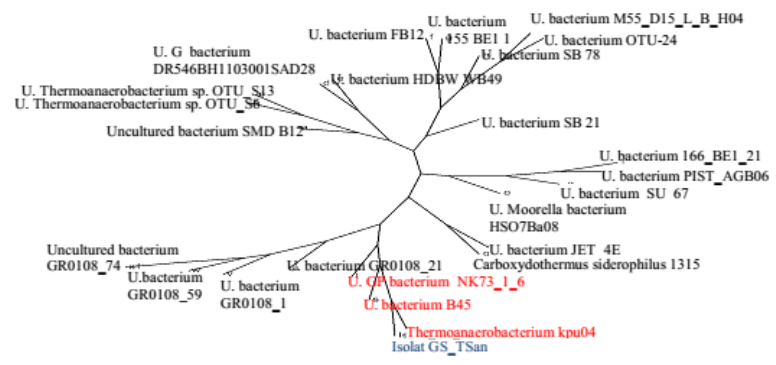

Gambar 6. Hasil konstruksi pohon filogenetik isolat GS_TSan dengan program Phylip 3.68 ed. metode

Distance Matriks menggunakan model Tree diag

(keterangan: U= Uncultured)

Ket: Warna biru= isolat GS_TSan; Warna merah= spesies lain yang mempunyai hubungan kekerabatan terdekat dengan isolat GS_TSan; Warna hitam= spesies lain yang dibandingkan

Tabel 1 menyajikan perbandingan bakteri hasil isolasi dengan bakteri yang memiliki hubungan kekerabatan terdekat berdasarkan fragmen gen $16 \mathrm{~S}$ rRNA.

\section{Uji enzim ekstraseluler termostabil}

Enzim a-amilase adalah enzim yang menghidrolisis ikatan a-1,4 glikosida secara acak di bagian dalam molekul baik pada amilosa maupun amilopektin dan menghasilkan glukosa sebagai produk akhirnya. Uji positif terhadap uji enzim $\alpha$-amilase adalah terbentuknya zona bening di sekitar koloni bakteri. Zona bening ini diakibatkan adanya aktivitas amilolitik enzim a-amilase yang dihasilkan oleh bakteri. Zona bening terjadi karena amilum telah terhidrolisis menjadi glukosa (Melliawati, dkk., 2006) sehingga iodium tidak terjerap pada aliran spiral amilum (amilosa), sedangkan warna biru terjadi karena adanya molekul iodium yang masuk dalam aliran spiral amilum (amilosa).

Enzim protease merupakan enzim yang mampu menghidrolisis protein menjadi asam- asam amino penyusunnya. Gelatin sebagai salah satu senyawa protein yang mempunyai struktur Ala-Gly-Pro-ArgGly-Glu-4Hyp-Gly-Pro- dan dengan adanya enzim protease (gelatinase) akan terurai menjadi asam-asam aminonya. Gelatin merupakan senyawa protein kompleks yang memadat pada proses pendinginan. Dengan keberadaan protease, ikatan peptida pada gelatin terputus yang menyebabkan gelatin terdegradasi. Efek dari degradasi gelatin adalah gelatin tidak memadat pada proses pendinginan [23].

Enzim P-galaktosidase dapat menghidrolisis laktosa menjadi glukosa dan galaktosa. Dalam uji enzim ini laktosa berfungsi sebagai induser dan ONPG sebagai substrat. ONPG yang berwarna kuning pucat akan dihidrolisis oleh enzim P-galaktosidase menjadi galaktosa dan ONP yang berwarna kuning.

Selulosa mampu dihidrolisis oleh enzim selulase dengan menghidrolisis ikatan $\mathrm{P}-1,4-$ glikosidik dalam polimer dan melepaskan glukosa [24]. Untuk mendeteksi adanya enzim selulase maka digunakan CMC sebagai substrat. Dalam reaksi ini, CMC (carboxymethil cellulose) akan dihidrolisis menjadi glukosa oleh selulase. Uji positif terhidrolisisnya CMC ditandai dengan terbentuknya zona bening di sekitar koloni bakteri saat penggenangan dengan congo red sedangkan daerah yang tidak ditumbuhi bakteri akan berwarna merah. Congo red akan membentuk ikatan hidrogen dengan polisakarida sehingga menghasilkan warna merah.

Dari hasil uji enzim ekstraseluler secara kualitatif diketahui bahwa isolat GS_MBan memiliki potensi enzim ekstraseluler a-amilase, protease dan P- 
galaktosidase sedangkan isolat GS_TSan memiliki potensi enzim ekstraseluler a-amilase dan protease.

\section{Kesimpulan}

Bakteri termofilik sumber air panas Gedongsongo dapat diisolasi dengan menggunakan pendekatan minimal media dalam kondisi anaerob dan diperoleh dua isolat tunggal yaitu isolat GS_MBan dan isolat GS_TSan. Isolat GS_MBan memiliki kemiripan dengan bakteri kelompok Anoxybacillus sp. sebesar 94-99\%; merupakan bakteri anaerob, berbentuk batang, gram positif, memiliki enzim ekstraseluler a-amilase, protease dan P-galaktosidase. Isolat GS_TSan memiliki kemiripan dengan bakteri kelompok Thermoanaerobacterium sp. sebesar 78-86\%; merupakan bakteri anaerob, berbentuk batang, gram negatif, memiliki enzim ekstraseluler $\alpha$-amilase dan protease.

\section{Daftar Pustaka}

[1] Z. Elnasser, A. Maraqa, W. Owais, A. Khraisat, Isolation and Characterization of New Thermophilic Bacteria in Jordan, The Internet Journal of Microbiology, 3, 2, (2006)

[2] Alexander Slobodkin, Barbara Campbell, S. Craig Cary, Elizaveta Bonch-Osmolovskaya, Christian Jeanthon, Evidence for the presence of thermophilic $\mathrm{Fe}(\mathrm{III})$-reducing microorganisms in deep-sea hydrothermal vents at $13^{\circ} \mathrm{N}$ (East Pacific Rise), FEMS Microbiology Ecology, 36, 2-3, (2001) 235-243 10.1111/j.1574-6941.2001.tbo0844.x

[3] Yoshihiko Sako, Satoshi Nakagawa, Ken Takai, Koki Horikoshi, Marinithermus hydrothermalis gen. nov., sp. nov., a strictly aerobic, thermophilic bacterium from a deep-sea hydrothermal vent chimney, International Journal of Systematic and Evolutionary Microbiology, 53, 1, (2003) 59-65 doi:10.1099/ijs.0.02364-0

[4] Thomas D. Brock, Katherine M. Brock, Robert T. Belly, Richard L. Weiss, Sulfolobus: A new genus of sulfur-oxidizing bacteria living at low $\mathrm{pH}$ and high temperature, Archiv für Mikrobiologie, 84, 1, (1972) 54-68 10.1007/BF00408082

[5] Sudhir Kumar, Koichiro Tamura, Masatoshi Nei, MEGA3: Integrated software for Molecular Evolutionary Genetics Analysis and sequence alignment, Briefings in bioinformatics, 5, 2, (2004) 150-163 http://dx.doi.org/10.1093/bib/5.2.150

[6] Jin-Woo Bae, Sung-Keun Rhee, Ja Ryeong Park, Byung-Chun Kim, Yong-Ha Park, Isolation of uncultivated anaerobic thermophiles from compost by supplementing cell extract of Geobacillus toebii in enrichment culture medium, Extremophiles, 9, 6, (2005) 477-485 http://dx.doi.org/10.1007/s00792005-0467-y

[7] Thomas D. Brock, Kathryn L. Boylen, Presence of Thermophilic Bacteria in Laundry and Domestic Hot-Water Heaters, Applied Microbiology, 25, 1, (1973) $72-76$

[8] Kellie Matzinger, The Importance of 16S rRNA Bacterial Spore Identification, in: Spore News, Mesa Labs, 2004 .

[9] Mark G. Wise, J. Vaun McArthur, Lawrence J. Shimkets, Bacterial diversity of a Carolina bay as determined by 16S rRNA gene analysis: confirmation of novel taxa, Applied and Environmental Microbiology, 63, 4, (1997) 1505-1514

[10] C. Allmang, M. Mougel, E. Westhof, B. Ehresmann, C. Ehresmann, Role of conserved nucleotides in building the 16S rRNA binding site of E. coli ribosomal protein S8, Nucleic Acids Research, 22, 18, (1994) 3708-3714

[11] Agustina L. N. Aminin, Fida Madayanti Warganegara, Pingkan Aditiawati, Simple enrichment and independent cultures to expand bacterial community analysis from gedongsongo hot spring, Journal of Bioscience and Bioengineering, 106, 2, (2008) 211-214

[12] Agustina L. N. Aminin, Fida Madayanti Warganegara, Pingkan Aditiawati, Akhmaloka, Culture-Independent and culture-dependent approaches on microbial community analysis at Gedongsongo (GS-2) hot spring, International Journal of Integrative Biology, 2, 3, (2008) 145-152

[13] R. Mcclelland, Gram's stain: the key to microbiology, Medical Laboratory Observer, 33, 4, (2001) 20-22, 25-28; quiz 30-21

[14] Y. K. Lee, H. J. Jung, H. K. Lee, Marine bacteria associated with the Korean brown alga, Undaria pinnatifida, Journal of Microbiology, 44, 6, (2006) 694-698

[15] Joseph Sambrook, David William Russell, Molecular Cloning: A Laboratory Manual, Cold Spring Harbor Laboratory Press, 2001.

[16] Ekaterina V. Pestova, Donald A. Morrison, Isolation and Characterization of Three Streptococcus pneumoniae Transformation-Specific Loci by Use of a lacZ Reporter Insertion Vector, Journal of Bacteriology, 180, 10, (1998) 2701-2710

[17] Artini Pangastuti, Dinamella Wahjuningrum, Antonius Suwanto, Isolasi, Karakterisasi, dan Kloning Gen Penyandi $\alpha$-Amilase Bakteri Halofil Moderat asal Bledug Kuwu, Hayati, 9, 1, (2002) 1014

[18] M. Castañeda-Agulló, Studies on The Biosynthesis of Extracellular Proteases By Bacteria : I. Serratia Marcescens. Synthetic and Gelatin Media, The Journal of General Physiology, 39, 3, (1956) 369-375

[19] Hidayah Ariffin, Mohd Ali Hassan, Umi Kalsom Md Shah, Norhafizah Abdullah, Farinazleen Mohd Ghazali, Yoshihito Shirai, Production of bacterial endoglucanase from pretreated oil palm empty fruit bunch by bacillus pumilus EB3, Journal of Bioscience and Bioengineering, 106, 3, (2008) 231-236 https://doi.org/10.1263/jbb.106.231

[20]Nining Betawati Prihantini, Dini Damayanti, Ratna Yuniati, Pengaruh konsentrasi medium ekstrak tauge (MET) terhadap pertumbuhan Scenedesmus isolat Subang, Makara Journal of Science, 11, 1, (2007) 1-9 http://dx.doi.org/10.7454/mss.v11i1.213

[21] Elke De Clerck, Marina Rodríguez-Díaz, Tom Vanhoutte, Jeroen Heyrman, Niall A. Logan, Paul De Vos, Anoxybacillus contaminans sp. nov. and Bacillus gelatini sp. nov., isolated from contaminated gelatin batches, International Journal of Systematic and Evolutionary Microbiology, 54, 3, (2004) http://dx.doi.org/10.1099/ijs.0.02960-0
941-946 
[22]Kohji Miyazaki, Chagan Irbis, Junya Takada, Aya Matsuura, An ability of isolated strains to efficiently cooperate in ethanolic fermentation of agricultural plant refuse under initially aerobic thermophilic conditions: Oxygen deletion process appended to consolidated bioprocessing (CBP), Bioresource Technology, 99, 6, (2008) 1768-1775 https://doi.org/10.1016/j.biortech.2007.03.045

[23] Frank B. Armstrong Amstrong, Buku Ajar Biokimia, EGC, 1995.

[24]Yukiko Nishida, Ken-ichi Suzuki, Yuya Kumagai, Hiroyuki Tanaka, Akira Inoue, Takao Ojima, Isolation and primary structure of a cellulase from the Japanese sea urchin Strongylocentrotus nudus, Biochimie, 89, 8, (2007) 1002-1011 https://doi.org/10.1016/j.biochi.2007.03.015 